\title{
ECONOMIC AND FINANCIAL VIABILITY PLAN FOR THE ENTERPRENEURSHIP OF A LYRIC THEATRE LOW-COST COMPANY: THE CASE OF ZARZUELA IN SPAIN
}

\author{
Jesús Manuel de SANCHA NAVARRO*, Luis PALMA MARTOS ${ }^{* *}$, \\ María Dolores OLIVER-ALFONSO ${ }^{* * *}$
}

\begin{abstract}
Taking into account that one of the major handicaps when undertaken in the cultural sector is the problem of cost and demand volatility, this paper aims to implement a viability plan for the entrepreneurship of a lyric theatre low-cost company, dedicated to Zarzuela performance, a type of Spanish music like Opera. Firstly, the cultural sector data are analysed in terms of supply and demand and secondly a viability plan is carried out for three years. According to the results it is concluded that this type of venture is very risky if you do not have grant or other financial resources, due to the variability of demand and the increase in unit costs as the artistic performance has a fixed production technology that cannot absorb the technical progress of the rest of the economy.
\end{abstract}

Keywords: entrepreneurship, viability plan, cultural economy, low-cost, music

JEL classification: M13, G30

\section{INTRODUCTION}

This work is part of a larger study that address the issues undertaken in the field of culture from an economic and financial view. We will focus on the situation of lyric theatre companies in Spain and more specifically on the supply and demand of Zarzuela companies, a typical Spanish musical genre similar to opera but with some differences.

In order to do so we will propose a business model, a plan of economic and financial feasibility for undertaking a low cost fictional lyrical theatre company or low-cost, since, as discussed below, the arts in general are affected by the "cost disease".

Therefore, our goal will be double: on the one hand to analyse the characteristics of the sector and, on the other, to create a viability plan up to 3 years for a company dedicated to Zarzuela performances, in order to come to conclusions and to propose some alternatives.

"Faculty of Economics and Business Science, University of Seville, Spain; e-mail: jsancha@us.es.

** Faculty of Economics and Business Science, University of Seville, Spain; e-mail: lpalma@us.es.

F*** Faculty of Economics and Business Science, University of Seville, Spain; e-mail: moliver@us.es. 
364 Jesús Manuel de Sancha NAVARRO, Luis Palma MARTOS, María Dolores Oliver-ALFONSO

First of all, two facts will be assumed; there is little supply relative to lyric theatre companies that produce Zarzuela and most companies in the sector have had or are having viability problems from economic-financial terms.

Our research question is: is it really feasible to undertake a lyric theatre company by reducing costs as much as possible, without meeting the required standards of quality?

Then we will answer this and other questions exposing the conceptual framework, methodological aspects and the application of the model, ending with the conclusions.

\section{LITERATURE REVIEW}

Cultural entrepreneurship is a new role within the cultural sector that has had a greater height from the 90s, due to increased interest in the economic dimensions of the arts (Klamer et al., 2006). We agree with Rick van der Ploeg (1999, cf. Klamer et al., 2006) when he states that a cultural entrepreneur must have the following qualities: knowledge and sensitivity to the arts and creative processes, as well as knowledge about marketing and market.

Prior to that, we can talk about the economy of art or culture economy as a subdiscipline that appears as field of application of economic science (Palma M. and Aguado Q., 2010). The work that originated it dates from 1966: Per-forming Arts: The Economic Dilemma. Its authors, Baumol and Bowen, observed an economic dilemma later called itself "cost disease", typical of the performing arts (theatre, opera, dance) which led to argue that the state should subsidize such activities. This dilemma referred to the problem of funding of the performing arts in relation to the increase in unit costs due to the delay in productivity.

In comparison with the industry, productivity increases occur more easily, because they use a lot of machines and equipment. In such industries the output per worker can be increased either by using more machinery or by investing in new equipment that incorporates enhanced technology.

Consequently, in the industry the amount of working time required to produce a physical unit of output decreases drastically decade after decade. By contrast, live arts are in the opposite situation.

In this case, the technology does not influence the productivity so strongly, since the work of the interpreter is an end in itself, not a means for the output of a product, and there is no way to increase output per hour (Baumol and Bowen, 1966). The artistic interpretation has a fixed production technology that cannot absorb the technical progress of the rest of the economy, so the actual average costs of interpretation grow more than other economic sectors, resulting in the interpreted arts are increasingly more expensive (Albi, 2003).

Another term to consider is the cultural industry, which was introduced in the fifties by Theodor Adorno and Max Horkheimer from the Frankfurt School, mainly to describe "the technological culture of the masses as opposed to the alternative of producing individual cultural pure and authentic arts" (Ministerio de Cultura de Colombia, 2003).

In its definition, developed in the late nineties, UNESCO eliminates the distinction between mass culture and elite culture, suggested by Adorno, and poses a notion of cultural industries associated with the concept of creation or creativity in a broad perspective. To Throsby (2001), the term refers to the economic potential of the cultural product to generate a sufficient return on capital and meet the demands of consumers.

Most of those working in the cultural sector, consider that cultural activity is an important contribution to the economy. Still, it is not easy to define the term because there are some uncertainties in capturing the nature of cultural goods and services, understood as 
Economic and Financial Viability Plan for the Entrepreneurship of a Lyric Theatre...

elements that represent creativity and incorporate some degree of intellectual property and convey a symbolic meaning. In recent years this is leading to a "cultural revolution" with an explosion of economic work in culture (Zingales, 2015).

\section{THEORETICAL BACKGROUND}

Currently, the cultural activity contributes $3.4 \%$ to GDP in Spain (Pulido, 2016). However, when speaking about the cultural sector in Spain, we must make reference to the severe crisis occurred in recent years, which has affected very negatively, assuming a serious threat to the survival of the performing arts (Albi, 2003). The culture has been virtually out of state public policy, with the exception of some measures that have damaged the already difficult situation that culture has to face, by its own nature, to be profitable.

One of the most criticized measures has been the rise of cultural VAT from 10 to $21 \%$ (Ramírez, 2013), which came into force on $1^{\text {st }}$ September 2012. This increase of 11 points has generated constant criticism, as no sector has received a drastic rise all at once, and in just 6 months the number of spectators dropped to $31 \%$. The percentage is alarming compared to other sectors; it also implies a differential element when compared with cultural VAT in other European countries such as France (5.5\%), Germany (7\%), Italy (12\%) and Portugal (13\%). The nearest approach is UK with 20\% (Pulido, 2016).

On the other hand, we can say broadly that spending on culture in Spain and in the region of Andalusia (where the activity of this work focuses on) has been declining, although a slight improvement was seen after 2014, as shown in Figure no. 1, where we can check the important cuts back that have occurred since 2009.

Figure no. 1 - Total expenditure dedicated to Culture in Spain

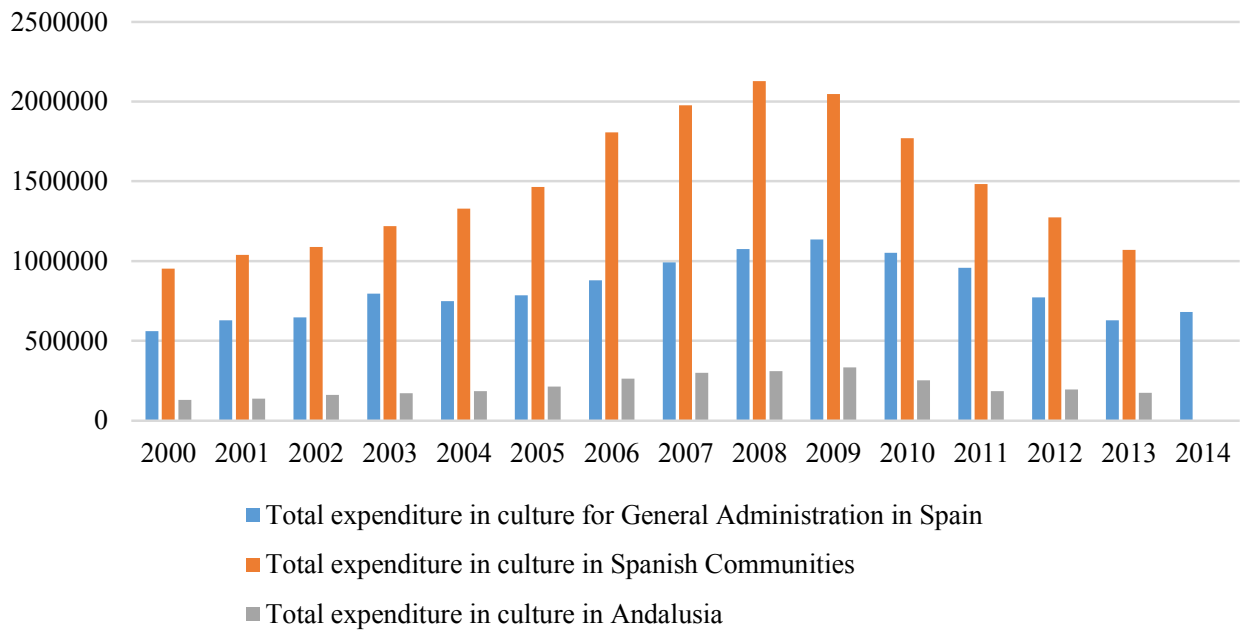

Source: Data from Ministerio de Educación Cultura y Deporte (2016a)

Following Throsby (2001), to analyse the cultural market, we must into account its components, the supply and the demand in particular. Regarding the second one, based on the tastes and preferences of consumers, we can say that it is influenced by the price of 
goods. Moreover, this demand is cumulative as a consumer has more contact with a type of music in particular, his knowledge and experience increases. Therefore, all will depend on the education and consumption he has had in the past.

Regarding the data of cultural participation offered by the Ministry of Education, Science and Sport for the last existing period, we can say that attending Zarzuela is quite low in relation to other cultural manifestations (see Figure no. 2), assuming a 1, 8\% of total attendance, below the opera. In a recent work by Pulido (2016) it was found that most attendees of zarzuela are more than 55 years old and that the $30 \%$ of those who have never attended are less than 18 years old. In addition, most respondents in this work recognize that the genre decline is due to little support from the public administration and the ignorance of youth (Pulido, 2016).

Figure no. 2 - Cultural Participation in Spain (2014-2015)

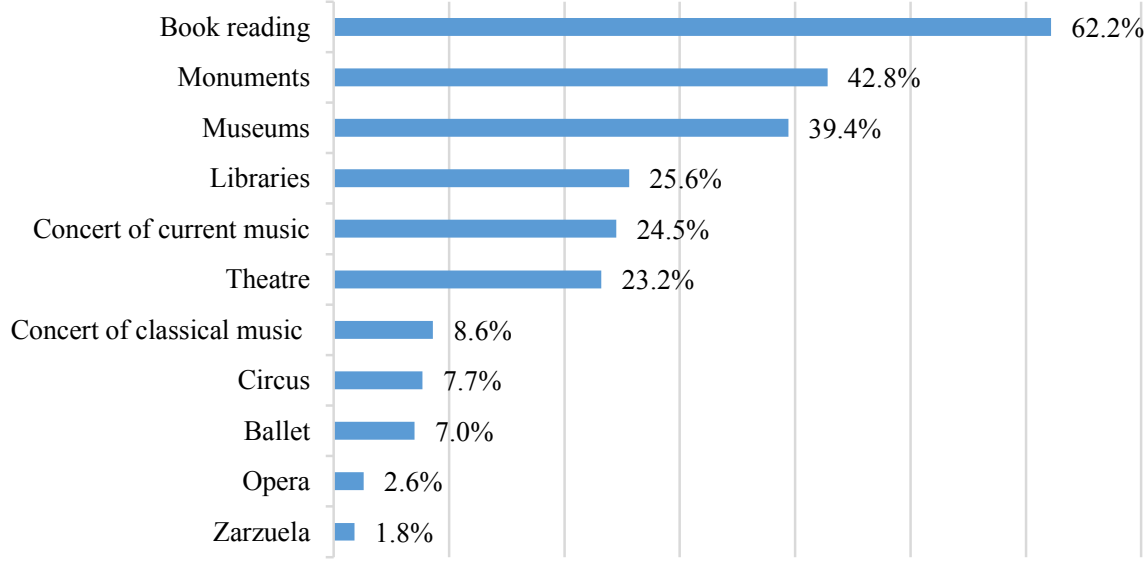

Source: Prepared with data from the survey of habits and practices (Ministerio de Educación Cultura y Deporte, 2016b).

In connection with the supply and, according to data from Culturabase (Ministerio de Educación Cultura y Deporte, 2016a), in 2014 there were a total of 83,257 companies in the industries and cultural services sector, of which 27,880 (a 33.49\%) were part of the design and creation of shows sector, a sector where the production of Zarzuela belongs.

This sector includes many companies that are not performing arts, but it helps us get an idea to frame the company is being dealt with in this project. A slight improvement from 2013 can be observed, as shown in Figure no. 3. On the other hand, this sector has decreased the amount raised from $€ 266,784,336$ in 2009 to $€ 211,521,267$ in 2014 , largely by the crisis commented before (Colomer, 2016).

Cultural and creative industries are fertile ground for innovation and technology. However, this is more likely in playback companies (recorded music, film industry, etc.) than in those dedicated to live music with more rigid goods price (opera, zarzuela, theatre ...). This can cause a long-term decline of this last type of offer producing a substitution effect in favour of the first, unless there is a demand stimulation through increased income, or through greater provision of grants or cultural aid (Herrero Prieto, 2010). 
Economic and Financial Viability Plan for the Entrepreneurship of a Lyric Theatre...

In the case of Andalusia, cultural and creative industries, especially SMEs can play a key role in regional and local development, be a source of innovation and contribute to the transfer of knowledge. It is therefore appropriate to analyse the factors that enable the development of new creative industries.

Figure no. 3 - Companies engaged in the design and creation of shows in Spain (2008-2014)

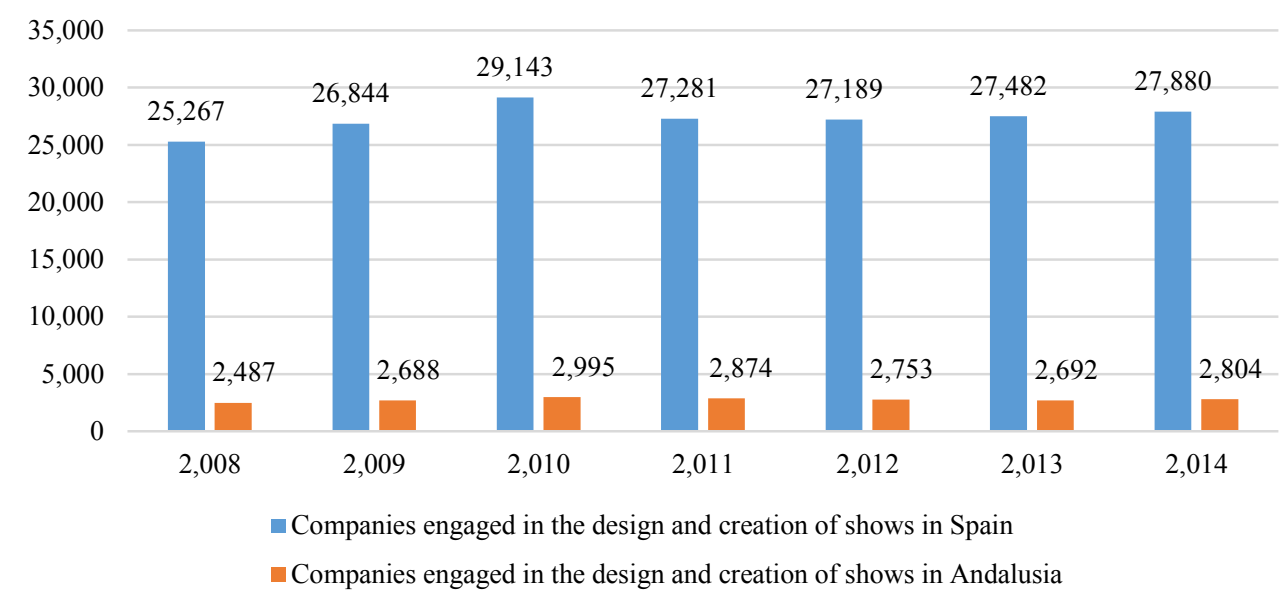

Source: Prepared with data from Ministerio de Educación Cultura y Deporte (2016a)

To analyse the supply of zarzuela in Spain we must refer to the Maps of programming associated stage areas (Pulido, 2016). To do this, we will consider the section dedicated to the lyric performances, making a difference between zarzuela and opera. As we can see in Figure no. 4, the supply of zarzuela, albeit timidly, has been declining in recent years, unlike the opera, which has had a raise, but has dropped again. It is not a good time for poetry in general.

Figure no. 4 - Total lyric performances, distinguishing Opera and Zarzuela from the total cultural offer (2012- 2015)

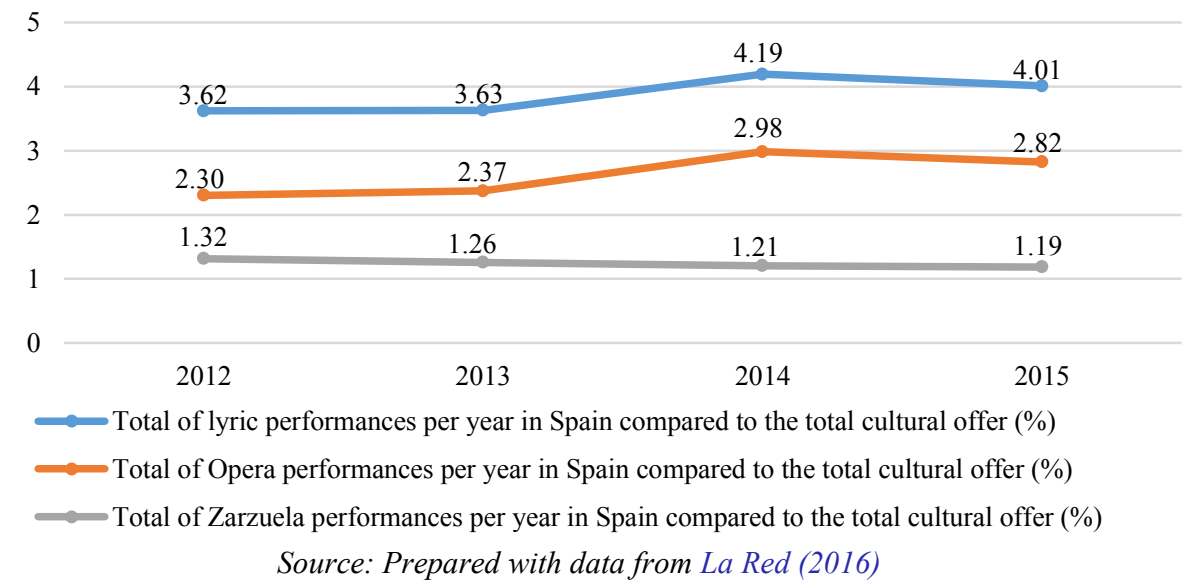


368 Jesús Manuel de Sancha NAVARRO, Luis Palma MARTOS, María Dolores Oliver-ALFONSO

We agree with Aragon and Baixauli (2010) when they recognize that achieving success with a new business idea is not easy and many entrepreneurs have difficulty to operate their new venture effectively. The launch of a new entrepreneurial activity is a complex task and during the development process entrepreneurs face multiple barriers, especially with organizations with little experience and limited resources, as in our case.

One of the main objectives of a business plan or viability study is to provide with information to help determine whether a project, apart from being a viable idea, it is also financially acceptable. We will have to analyse whether this viability is related to the objectives to achieve results and sufficient liquidity as it will be the first thing that promoters are going to require (Muñiz González, 2010).

Some authors define the company from a financial perspective, as a succession of investment and financing projects in time. This implies that the finance function will have a double aspect; on the one hand, it should try to manage the economic structure, while on the other, it cannot forget the financial structure. The financial function is responsible for finding the best financing alternatives and negotiate costs and deadlines, so that they meet the investment needs of the company. It can be said that investing and financing are two sides of the same coin (Camara et al., 2000).

To encourage entrepreneurship, especially among young people, we must make reference to the existence of business incubators. They are designed as places where companies which start their activity can access to infrastructure services, training, support and follow-up business plan for two or three years (Martínez et al., 2011).

One option that we propose in this entrepreneurial project, adapted to new times, is to build on the low-cost philosophy. According to García Agustín (2015, p. 19), "in a context of global economic crisis where we live, the consumer appeal of obtaining lower prices is very big". The purpose is not to offer cheap and bad products, now the objective is to offer quality at the lowest possible price, through a series of strategies that enable cost reduction. There are many sectors that have adopted this type of business model, however, it is noteworthy that the music industry has been slow to incorporate it.

However, we have not found anything about lyric companies with this model, which it is very interesting for us, since we pretend to defend our model. What seems to be clear, as Kotler and Scheff (1997) think, is that most lyric theatre companies are subject to high fixed costs which they must met, regardless of the box office, hence we want to propose a model that starts from the cost reduction.

On the other hand, we must focus our attention on the determinants of supply and demand that may condition and / or affect the outcome or viability of the project that we expose below. From the supply side, we have not found many companies offering a similar product, in the case of Andalusia, where we plan to undertake the project, only we found five with prices ranging between $15-25 €$.

It is also noteworthy that important theatres as the Maestranza Theatre in Seville and the Cervantes Theatre in Malaga, hardly offer Zarzuela in its annual programs, compared to other more expensive genres like Opera. This has already been observed in Figure no. 4. From the point of view of the demand, the Zarzuela is a genuine, humorous and fun especially middleaged Spanish genre, with some welcoming by the audience. One problem, as we have seen, is funding, because the provision of grants is virtually non-existing. In this respect, different alternatives are emerging, such as crowdfunding through social networks (e.g. Verkami), which allow costs to create, produce, edit, share and spread to be lower. The crowdfunding, a process to raise financing in which patrons are a crowd, is being able to finance projects of 
Economic and Financial Viability Plan for the Entrepreneurship of a Lyric Theatre...

cultural and social interest that would never have to see the light otherwise, due to the reduction in public investment (Rodríguez de las Heras Ballell, 2013, p. 101).

Finally, we consider the Zarzuela is a genre that could be lost, as for decades it was not composed and, also, there are not currently many companies dedicated to its performance and spread, hence the opportunity to undertake business. But to deal with undertaking a lyric theatre company of Zarzuela we must talk about the concepts of "Zarzuela" and "Zarzuela Company". The Zarzuela is a musical scenic genre of Spain with instrumental parts, vocal parts (solos, duets, choral work ...) and spoken parts "and has a history as old as our national theatre" (Muñoz, 1946, p. 19). It can be said that it is the Spanish form of operetta, a theatre performance that, unlike Opera, is not entirely musical, but alternating spoken and musical parts. It is a hybrid genre, that is, sung, spoken and performed -the music came mostly in the "sweet" part of the performance.

According to the Dictionary of the Zarzuela (Casares Rodicio and al., 2002), in the theatre language a zarzuela company is a group of singers or actors who are hired and works, giving the public lyric, dramatic, comical performances, etc. This organizational system made possible the great history of zarzuela in Spain and in America, where, besides own formations, many Spanish companies went throughout the nineteenth and twentieth centuries.

\section{DATA AND METHODOLOGY}

As we said earlier, two established facts will be assumed. On the one hand, there is little supply in relation to lyric theatre companies that produce zarzuela (especially in Andalusia) and on the other hand, most companies in the sector have had or are having problems of viability from an economic and financial point of view.

Therefore, we intend to answer whether is economically feasible to undertake a lyric theatre company reducing costs as much as possible, without having a decline in the quality offered.

For this work, we have simulated the creation of a company called LIRICART (with Lyric with Art) whose mission will consist of the performance of lyric theatre performances of Zarzuela for both adults and children. For this, the company, based in Seville, will travel every weekend to a population of the Andalusian geography after negotiating the performance with its theatre (or similar institution). The theatre should meet the capacity requirements previously estimated by the company.

In each show there will be a narrator who will tell the adventures and misadventures of the protagonists of the show, a duo consisting of soprano and tenor, and a pianist. Thus, each performed play (duo or romanza) is perfectly connected and argued, giving cohesion to the show. All with a touch of humour and charm, suitable for all types of audiences.

Therefore, the idea of this business, taking into account the existing competition and the economic situation, is particularly to provide the public with a different offer based on the benefits of "low-cost" model that currently prevails in many business areas: a company with few components to reduce costs and which focuses on acting in theatres where large companies have problems of profitability to perform, for the limited existing capacity. We want to reflect an appointment on this model: "the low-cost upwards is a value and an opportunity for companies that are able to extract the maximum efficiency of its business activity".

Elements necessary to form a lyric theatre low-cost company

We will need a manager, two lyric soloists, an actor, an accompanist pianist, a van Citroen Jumper 9 seats, a bank account, a local test (manager's property), notary and agency 
370 Jesús Manuel de Sancha NAVARRO, Luis Palma MARTOS, María Dolores Oliver-ALFONSO

fees, sets, props, costumes and lighting, advertising through billboards, newspapers and radio, rental service of incubator and telephone line.

The financing of the company will be run by three partners who will bring 5,000 €, thus constituting a share capital of $€ 15,000$. One of the partners will be autonomous and will work as a manager and a pianist in the performances. The other two partners would belong to the family of the first one, exercising of equity partners.

Regarding the grants and given the situation of widespread cutbacks that currently exists, has been unfeasible to have some help in this regard, according to information provided by the Department of Business Incubation in the City of Seville.

\section{Plan of itinerant theatre performance around different towns of Andalusia}

The show will consist of a piano recital with a selection or anthology of the main romanzas of Zarzuela, connected by a theatrical red thread.

The LIRICART business will start in January, so at first it will be necessary to establish a series of rehearsals in order to implement the repertoire of arias and duets for soprano and tenor, and also to prepare the staging with the actor who will make the narrator and will direct the singers.

These rehearsals will take two months and will be programmed by the accompanist at the place of the rehearsals decided by the manager. Duets and romanzas will be decided, the voice will be adapted to piano, texts will be selected and scenic movements will be designed. There will be two months of rehearsals that will prepare the entire show to perfection. These rehearsals will last an average of two hours and the show is scheduled for one hour and a half, (the final approximate duration.)

In the last week of preparation, a dress rehearsal where all parties will act with selected and appropriate attire for this purpose will be made, and the small stage will be set with references to the city of Madrid in the nineteenth century. This is a perfectly removable stage, made with boards and folded fabrics, which can be transported at the rear of the van.

Once the show starts performing around the various populations and theatres, it will be not necessary to rehearse on weekdays, except the rehearsal at the venue of the show, one hour before the performance starts.

The days of the performances everyone will meet at a place in Seville, the company headquarters, to go to the corresponding destination of that weekend. The shows will be at 8.30 or $9 \mathrm{pm}$ (as winter or summer time) and they will arrive at the theatre about three hours before the start of the show. Thus, during the first hour sets will be unloaded and mounted, and the next hour and a half they will warm-up and go through/review the performance. The last half hour the doors will be open to the public (the curtain will be brought down), while all actors will be at the backstage dressing up and getting prepared for the play. When every show ends, and as something characteristic of the company, they will greet the audience at the front door, thanking for the visit. Approximately in one hour everything will be disassemble, and after a light dinner, the whole company will take the way back.

The company is created with the purpose to be in operation for at least 3 years, with the following scope of performance:

- First year: Performances in Seville and Huelva.

- Second year: Performances in Cadiz, Malaga and Cordoba.

- Third year: Performances in Jaen, Granada and Almeria. 


\section{RESULTS}

\section{Financial statements}

Before commenting on the composition of pension financial statements, balance sheets for the three years of the project, we note that optimistic and pessimistic scenarios for the entire project have been established. It basically consists of assuming estimated sales with a decrease of $25 \%$ for the pessimistic scenario compared to the optimistic scenario.

\section{The income and expenses of the activity}

The revenue will be fully brought into the company with its business activity, i.e., the lyric theatre play for which, as already mentioned, an optimistic and pessimistic scenario have been applied.

The amount of the figure of revenue has been calculated by multiplying the price of the ticket, $10 €$, by the estimation of tickets sold. This estimate was done based on the size of the population, taking as a model Seville, where, for a theatre of about 500 seats, an optimistic scenario would have a sale of between 350 and 400 tickets. This has led us to the following result (see Table no. 1):

Table no. 1 - Optimistic and pessimistic estimates of sales, according to population

\begin{tabular}{|l|}
\hline OPTIMISTIC ESTIMATES ACCORDING POPULATION \\
\hline $0-4.999$ inhabitants $=100$ tickets \\
\hline $5.000-9.999$ inhabitants $=150$ tickets \\
\hline $10.000-49.999$ inhabitants $=200$ tickets \\
\hline $50.000-99.999$ inhabitants $=250$ tickets \\
\hline $100.000-249.999$ inhabitants $=300$ tickets \\
\hline More than 250.000 inhabitants $=350$ tickets \\
\hline PESSIMISTIC ESTIMATES $=\mathbf{7 5 \%}$ of optimistic \\
\hline
\end{tabular}

With these data we can make an estimate of optimistic and pessimistic income that we will have in the company based on the population of the different locations where the company will act. The total estimate tickets and performances were, respectively, 8,000 and 39 for the first year (result of adding Seville - Huelva), 10,550 and 47 for the second year (CádizMalaga-Cordoba), and 9,150 and 49 for the third (Jaen - Granada - Almeria). Due to the cost of living, we have applied an increase of 3\% per year to all costs incurred, being barely noticeable in the case of ticket prices. Therefore, we wanted to keep the price of $10 €$ for the first and second year, and apply that rise the last year, changing the ticket entrance to $12 €$.

All this allows us to calculate the income which would be in the case of the optimistic scenario the result of multiplying the above figures by the price of the ticket entrance for that year situation. Pessimistic revenue is a $25 \%$ less than the optimistic.

Optimistic revenue estimates Year $1=80,000 €$.

Optimistic revenue estimates Year $2=105,500 €$.

Optimistic revenue estimates Year $3=203,400 €$.

Pessimistic revenue estimates Year $1=60,000 €$.

Pessimistic revenue estimates Year $2=79,125 €$.

Pessimistic revenue estimates Year $3=152,550 €$. 
372 Jesús Manuel de Sancha NAVARRO, Luis Palma MARTOS, María Dolores Oliver-ALFONSO

In accordance with the income we can calculate the cost of the theatre that is, $10 \%$ on the income, depending on whether it is optimistic or pessimistic. They have been taken into account for calculating the cost of diesel van and the distance from Seville city to different destinations, where they will go and return on the same day (to save money in accommodation).

Regarding the expenditure for the implementation and development of our company during the first year we will have the following:

- The manager. Monthly salary of $800 €$.in the first year

- Two soloists (soprano and tenor). $600 €$ monthly each.

- An actor. $600 €$ monthly.

- An accompanist pianist. $600 €$ monthly.

- Scenography assistant (to build sets and stages). $400 €$ monthly.

- A van Citroën Jumper 9 seats 2 nd hand. 10,000 € cash. In addition, the first year it will be amortized by the third part, $3,333 €$ (useful life three years).

- Insurance of the van. $600 €$ per year.

- Expenses of the bank account. $10 €$ per year.

- Notary fees. $310 €$ per year (first year only).

- Agency expenses. $€ 600$ per year.

- Sets, props, costumes and lighting. $€ 2,025$ (first year only). In addition, the first year it will be amortized over his third part, $675 €$ (useful life three years).

- Posters, newspapers and radio advertising. $€ 200$ per play.

- Rental business incubator service provided by the city of Seville with lighting and Wi-Fi included. It is the physical headquarters which will cost $90 €$ per month, $€ 1,080$ full year (according to the CREA office of the City of Seville).

- Flat rate contract for the phone. $€ 700$ per year.

- Fuel expenditure. The van consumes 0.06 litres per kilometre. The diesel price in November 2013 was around $€ 1.38$ per litre.

- Expenses for the cost of the theatre. Since most theatres apply a percentage based on sales (with some exceptions we have studied), and this percentage is between 10 and $20 \%$ of sales, we have chosen to apply a $10 \%$ to total estimated sales in both the optimistic and pessimistic situation.

Expenses for the cost of the theatre in an optimistic scenario: Year $1=8,000 €$.

Expenses for the cost of the theatre in an optimistic scenario: Year $2=10,550 €$.

Expenses for the cost of the theatre in an optimistic scenario: Year $3=20,340 €$.

Expenses for the cost of the theatre in a pessimistic scenario: Year $1=6,000 €$.

Expenses for the cost of the theatre in a pessimistic scenario: Year $2=7,913 €$.

Expenses for the cost of the theatre in a pessimistic scenario: Year $3=15,255 €$.

- Social Security. $30 \%$ of the total amount of wages and salaries.

All these expenses will remain the next two years, and just transport and sets will have a depreciation expense. Obviously there won't be notary fees, but there will be other maintenance expenditure for sets from Year 2 (for possible repairs) in the amount of $200 €$. Moreover, as we have said above, a rise of $3 \%$ year on year will be applied on all costs except for ticket prices that will only rise the third year amounting to $12 €$. 
Economic and Financial Viability Plan for the Entrepreneurship of a Lyric Theatre...

We need to add financial income of $300 €$ for the last year due to the deposit of 20,000 $€$ year term deposit considering the cash surplus we have in the bank. This income comes from the $1.5 \%$ interest on the amount of $20,000 €$.

\section{Profit and loss account}

\section{- Optimistic scenario:}

We can see in Tables no. 2 and no. 3 the distribution of the profit and loss for the three years studied.

Table no. 2 - Profit and loss in an optimistic situation

\begin{tabular}{|c|c|c|c|}
\hline Profit and Loss Account & $\begin{array}{l}\text { First } \\
\text { year }\end{array}$ & $\begin{array}{c}\text { Second } \\
\text { year }\end{array}$ & $\begin{array}{l}\text { Third } \\
\text { year }\end{array}$ \\
\hline \multicolumn{4}{|l|}{ A) Continuing operations } \\
\hline 1. Net turnover & $80.000 €$ & $105.500 €$ & $109.800 €$ \\
\hline a) Sales & $80.000 €$ & $105.500 €$ & $109.800 €$ \\
\hline 6. Personal expenses & $-56.160 €$ & $-57.845 €$ & $-59.195 €$ \\
\hline a) Salaries & $-43.200 €$ & $-44.496 €$ & $-45.534 €$ \\
\hline b) Social charges & $-12.960 €$ & $-13.349 €$ & $-13.660 €$ \\
\hline 7. Other operating expenses & $-19.448 €$ & $-24.933 €$ & $-27.482 €$ \\
\hline d) Other current operating expenses & $-19.448 €$ & $-24.933 €$ & $-27.482 €$ \\
\hline - Annual bank charges & $-10 €$ & $-10 €$ & $-11 €$ \\
\hline - Publicity & $-7.800 €$ & $-9.682 €$ & $-10.397 €$ \\
\hline - Flat rate mobile $1000 \mathrm{~min}$ & $-700 €$ & $-721 €$ & $-743 €$ \\
\hline - Incubator rent & $-1.080 €$ & $-1.112 €$ & $-1.146 €$ \\
\hline - Transport insurance & $-600 €$ & $-618 €$ & $-637 €$ \\
\hline - Notary fees & $-310 €$ & $0 €$ & $0 €$ \\
\hline - Agency & $-600 €$ & $-618 €$ & $-637 €$ \\
\hline - Theatre costs & $-8.000 €$ & $-10.550 €$ & $-10.980 €$ \\
\hline - Fuel & $-348 €$ & $-1.421 €$ & $-200 €$ \\
\hline - Maintaining decorated & $0 €$ & $-200 €$ & $-2.733 €$ \\
\hline 8. Depreciation and amortization & $-4.008 €$ & $-4.008 €$ & $-4.008 €$ \\
\hline Net Operating Income & $384 €$ & $18.714 €$ & $19.116 €$ \\
\hline 13. Financial incomes & $0 €$ & $0 €$ & $300 €$ \\
\hline Net Gains (losses) on Financial Assets and Liabilities & $0 €$ & $0 €$ & $300 €$ \\
\hline Profit or Loss Before Tax & $384 €$ & $18.714 €$ & $19.416 €$ \\
\hline 18. Income tax & $58 €$ & $2.807 €$ & $2.912 €$ \\
\hline Profit or Loss from Ordinary Activities & $326 €$ & $15.907 €$ & $16.504 €$ \\
\hline
\end{tabular}

Source: Author's calculations

In the optimistic scenario, and mainly due to the estimates of the inputs, we see a result not only good but in continued growth for the three years, going from $326 €$ to $15,907 €$ in the first two years, and to $16,504 €$ in the third year. Thus we see how, at first glance, the optimistic option is very interesting for the result achieved.

\section{- Pessimistic scenario:}

We can see in Table no. 3 the profit and loss according to the pessimistic scenario, that according to our expertise in the sector is the result of the $75 \%$ of figures of optimistic sales. Most of the remaining costs are kept (so we will not repeat). In this scenario we cannot qualify 
374 Jesús Manuel de Sancha NAVARRO, Luis Palma MARTOS, María Dolores Oliver-ALFONSO

for financial income due to the small volume of cash collected at the end of the period. This causes a negative result in all the three periods amounting to $-4,751 €$ in the last year.

Table no. 3 - Profit and loss in a pessimistic situation

\begin{tabular}{|l|r|r|r|}
\hline Profit and Loss Account & \multicolumn{1}{c|}{$\begin{array}{c}\text { First } \\
\text { year }\end{array}$} & \multicolumn{1}{c|}{$\begin{array}{c}\text { Second } \\
\text { year }\end{array}$} & \multicolumn{1}{c|}{$\begin{array}{c}\text { Third } \\
\text { year }\end{array}$} \\
\hline A) Continuous operations & & & \\
\hline 1. Net turnover & $60.000 €$ & $79.125 €$ & $82.350 €$ \\
\hline a) Sales & $-50.000 €$ & $79.125 €$ & $82.350 €$ \\
\hline 6. Personal expenses & $-43.200 €$ & $-44.496 €$ & $-45.534 €$ \\
\hline a) Salaries & $-12.960 €$ & $-13.349 €$ & $-13.660 €$ \\
\hline b) Social charges & $-17.448 €$ & $-22.295 €$ & $-24.737 €$ \\
\hline 7. Other operating expenses & $-17.448 €$ & $-22.295 €$ & $-24.737 €$ \\
\hline d) Other current operating expenses & $-10 €$ & $-10 €$ & $-11 €$ \\
\hline - Annual bank charges & $-7.800 €$ & $-9.682 €$ & $-10.397 €$ \\
\hline - Publicity & $-700 €$ & $-721 €$ & $-743 €$ \\
\hline - Flat rate mobile 1000min & $-1.080 €$ & $-1.112 €$ & $-1.146 €$ \\
\hline - Incubator rent & $-600 €$ & $-618 €$ & $-637 €$ \\
\hline - Transport insurance & $-310 €$ & $0 €$ & $0 €$ \\
\hline - Notary fees & $-600 €$ & $-618 €$ & $-637 €$ \\
\hline - Agency & $-6.000 €$ & $-7.913 €$ & $-8.235 €$ \\
\hline - Theatre costs & $-348 €$ & $-1.421 €$ & $-200 €$ \\
\hline - Fuel & $0 €$ & $-200 €$ & $-2.733 €$ \\
\hline - Maintaining decorated & $-4.008 €$ & $-4.008 €$ & $-4.008 €$ \\
\hline Net Operating Income & $-17.616 €$ & $-5.023 €$ & $-5.589 €$ \\
\hline 13. Financial incomes & $0 €$ & $0 €$ & $0 €$ \\
\hline Net Gains (losses) on Financial Assets and Liabilities & $0 €$ & $0 €$ & $0 €$ \\
\hline Profit or Loss Before Tax & $-17.616 €$ & $-5.023 €$ & $-5.589 €$ \\
\hline 18. Income tax & $2.642 €$ & $753 €$ & $838 €$ \\
\hline Net Operating Income & $-14.974 €$ & $-4.270 €$ & $-4.751 €$ \\
\hline Profit or Loss from Ordinary Activities & &
\end{tabular}

Source: Author's calculations

\section{Balance sheet}

\section{- Optimistic scenario:}

As noted in Table no. 4, our company has non-current assets of $8,017 €$ for the first year, consisting of a truck (means of transport) and some backdrops as well as elements of props that will be needed for the performances. These non-current assets will decrease as they are depreciated, according to their estimated useful life which as stated above.

Current assets consist of:

a) The customers' account, since on average the theatres will pay to us for the tickets within 30 days.

b) Short-term financial investments that we will have the third year as a result of the fixed-term placement of $€ 20,000$ for a period of a year with a $1.5 \%$ interest.

c) Lastly, current assets are integrated in the bank account, as we see happening in the first year of $5,489 €$ to $26,547 €$ in the third. The final treasury/cash of every year has been obtained based on the following assumptions:

- The sale is charged, as we said, within 30 days. 
Economic and Financial Viability Plan for the Entrepreneurship of a Lyric Theatre...

- Wages are paid at the beginning of the following month (30 days).

- The expenses which are also paid at the beginning of the following month are the Telephone, agency, tax payments and social security creditor.

- All other expenses are paid at the beginning of each month, such as rental of the incubator, or transport insurance, which is paid at the beginning of the year.

Table no. 4 - Balance sheet of the pessimistic scenario

\begin{tabular}{|c|c|c|c|}
\hline Optimistic Balance Sheet & $\begin{array}{l}\text { First } \\
\text { year }\end{array}$ & $\begin{array}{c}\text { Second } \\
\text { year }\end{array}$ & $\begin{array}{l}\text { Third } \\
\text { year }\end{array}$ \\
\hline A) Non-Current Assets & $8.017 €$ & $4.008 €$ & $\mathbf{0} €$ \\
\hline II. Tangible fixed assets & $8.017 €$ & $4.008 €$ & $0 €$ \\
\hline Means of transport & $10.000 €$ & $10.000 €$ & $10.000 €$ \\
\hline Accumulated depreciation of means of transport & $-3.333 €$ & $-6.667 €$ & $-10.000 €$ \\
\hline Other tangible fixed assets & $2.025 €$ & $2.025 €$ & $2.025 €$ \\
\hline Accumulated depreciation of other tangible fixed assets & $-675 €$ & $-1.350 €$ & $-2.025 €$ \\
\hline VI. Deferred tax assets & $0 €$ & $0 €$ & $0 €$ \\
\hline Deferred tax assets & $0 €$ & $0 €$ & $0 €$ \\
\hline B) Current Assets & $12.155 €$ & $34.964 €$ & $55.697 €$ \\
\hline III. Commercial debtors and other pending and other receivables & $6.666 €$ & $8.792 €$ & $9.150 €$ \\
\hline Clients & $6.666 €$ & $8.792 €$ & $9.150 €$ \\
\hline V. Short-term financial investments & $0 €$ & $0 €$ & $20.000 €$ \\
\hline Debt securities & $0 €$ & $0 €$ & $20.000 €$ \\
\hline VII. Cash and other similar liquid assets & $5.489 €$ & $26.172 €$ & $26.547 €$ \\
\hline Bank & $5.489 €$ & $26.172 €$ & $26.547 €$ \\
\hline Total Assets & $20.172 €$ & $38.972 €$ & $55.697 €$ \\
\hline A) Net Worth & $15.326 €$ & $31.233 €$ & $47.737 €$ \\
\hline I. Capital & $15.000 €$ & $15.000 €$ & $15.000 €$ \\
\hline Social capital & $15.000 €$ & $15.000 €$ & $15.000 €$ \\
\hline III. Reserves & $0 €$ & $326 €$ & $16.233 €$ \\
\hline Legal reserve & $0 €$ & $326 €$ & $16.233 €$ \\
\hline VII. Result of the year & $326 €$ & $15.907 €$ & $16.504 €$ \\
\hline Result of the year & $326 €$ & $15.907 €$ & $16.504 €$ \\
\hline B) Non-Current Liabilities & $\mathbf{0} €$ & $\mathbf{0 €}$ & $\mathbf{0} €$ \\
\hline C) Current Liabilities & $4.846 €$ & $7.739 €$ & $7.960 €$ \\
\hline V. Trade and other payables & $4.846 €$ & $7.739 €$ & $7.960 €$ \\
\hline Creditors for services rendered & $108 €$ & $112 €$ & $115 €$ \\
\hline Pending remuneration & $3.600 €$ & $3.708 €$ & $3.795 €$ \\
\hline Accrued social security taxes payable & $1.080 €$ & $1.112 €$ & $1.138 €$ \\
\hline Tax authorities, the creditor balance for Corporation Tax & $58 €$ & $2.807 €$ & $2.912 €$ \\
\hline Total Net Worth and Liabilities & $20.172 €$ & $38.972 €$ & $55.697 €$ \\
\hline
\end{tabular}

Source: Author's calculations

With respect to the net worth, it has been paid off into social capital/capital stock, consisting of a contribution of $15,000 €(5,000 €$ for each of the three partners) as well as the capital buffers amounting to 0 logically the first year and to $16,233 €$ the third and the result for the year. Regarding the result/outcome, it grows very much from the first to the second year, from $326 €$ to $15,907 €$. However, from the second to the third year it grows slightly less, amounting to $16,504 €$. During the three years it is not intended to pay dividends. 
376 Jesús Manuel de Sancha NAVARRO, Luis Palma MARTOS, María Dolores Oliver-ALFONSO

For the operation of this company, it is formed entirely from own funds, trying to avoid incurring debts with credit institutions. Therefore, the non-current liability is equal to 0 in all the three periods.

Finally, current liabilities consist of commercial creditors (telephone flat rate contract and legal and administrative services), outstanding remunerations, the social security of the workers and taxes of Treasury. They are debts that are paid at the beginning of the next year. These current liabilities increased by $60 \%$ from the first year to the second year, and $92 \%$ from the second year to the third year.

We can conclude that the total assets and liabilities have increased an average of $60 \%$ per year approximately during the three years, from $20,171 €$ to $55,697 €$.

\section{- Pessimistic scenario:}

As for the pessimistic scenario, as we said above, it is based on the estimated sales, a $25 \%$ below the optimistic figure, causing the balance we see in Table no. 5 .

Table no. 5 - Balance sheet of the pessimistic scenario

\begin{tabular}{|c|c|c|c|}
\hline Pessimistic Balance Sheet & $\begin{array}{l}\text { First } \\
\text { year }\end{array}$ & $\begin{array}{l}\text { Second } \\
\text { year }\end{array}$ & $\begin{array}{l}\text { Third } \\
\text { year }\end{array}$ \\
\hline A) Non-Current Assets & $10.659 €$ & $7.404 €$ & $4.234 €$ \\
\hline II. Tangible fixed assets & $8.017 €$ & $4.008 €$ & $0 €$ \\
\hline Means of transport & $10.000 €$ & $10.000 €$ & $10.000 €$ \\
\hline Accumulated depreciation of means of transport & $-3.333 €$ & $-6.667 €$ & $-10.000 €$ \\
\hline Other tangible fixed assets & $2.025 €$ & $2.025 €$ & $2.025 €$ \\
\hline Accumulated depreciation of other tangible fixed assets & $-675 €$ & $-1.350 €$ & $-2.025 €$ \\
\hline VI. Assets by differed taxes & $2.642 €$ & $3.396 €$ & $4.234 €$ \\
\hline Assets by deferred taxes & $2.642 €$ & $3.396 €$ & $4.234 €$ \\
\hline Current Assets & $15.156 €$ & $14.285 €$ & $27.820 €$ \\
\hline III. Commercial debtors and other accounts receivable & $5.000 €$ & $6.594 €$ & $6.863 €$ \\
\hline Clients & $5.000 €$ & $6.594 €$ & $6.863 €$ \\
\hline VII. Cash and other similar liquid assets & $10.156 €$ & $7.691 €$ & $20.957 €$ \\
\hline Bank & $10.156 €$ & $7.691 €$ & $20.957 €$ \\
\hline Total Assets & $25.815 €$ & $21.689 €$ & $32.054 €$ \\
\hline A) Net Worth & $21.026 €$ & $16.759 €$ & $27.006 €$ \\
\hline I. Capital & $36.000 €$ & $36.000 €$ & $51.000 €$ \\
\hline Social capital/capital stock & $36.000 €$ & $36.000 €$ & $51.000 €$ \\
\hline Result from previous years & $0 €$ & $-14.974 €$ & $-19.243 €$ \\
\hline Negative results from previous years & $0 €$ & $-14.974 €$ & $-19.243 €$ \\
\hline VII. Result of the year & $-14.974 €$ & $-4.270 €$ & $-4.751 €$ \\
\hline Result of the year & $-14.974 €$ & $-4.270 €$ & $-4.751 €$ \\
\hline B) Non-Current Liability & $\mathbf{0} €$ & $\mathbf{0} €$ & $\mathbf{0} €$ \\
\hline C) Current Liability & $4.788 €$ & $4.932 €$ & $5.048 €$ \\
\hline V. Commercial creditors and other outstanding payments & $4.788 €$ & $4.932 €$ & $5.048 €$ \\
\hline Creditors for services rendered & $108 €$ & $112 €$ & $115 €$ \\
\hline Outstanding remunerations & $3.600 €$ & $3.708 €$ & $3.795 €$ \\
\hline Accrued social security taxes payable & $1.080 €$ & $1.112 €$ & $1.138 €$ \\
\hline Tax authorities, the creditor balance for Corporation Tax & $0 €$ & $0 €$ & $0 €$ \\
\hline Total Net Worth and Liabilities & $25.8135 €$ & $21.689 €$ & $32.054 €$ \\
\hline
\end{tabular}


Economic and Financial Viability Plan for the Entrepreneurship of a Lyric Theatre...

In relation to the assets, it is remarkable the account of deferred tax assets, resulting from losses obtained in the three periods studied and which have increased that account. On the other hand, we must also refer to the bank account, which in the first year is $€ 10,156$ and decreases the second year to $€ 20,957$ the last year. Compared with the optimistic scenario, we observe that in both cases the bank increased much more, amounting to $€ 26,547$.

In net equity, the most important aspect is the need to increase the initial payment of $€$ 15,000 to $€ 21,000$ more to compensate the losses and avoid the treasury to be in the red. This causes half of the first year each partner disburses $€ 7,000$ on the initial capital, for a total of $36,000 €$. The three years incur losses, the third year of $€-4,751$, which causes a new capital contribution of $15,000 €$ by the partners for that year, amounting to a total of 51,000 $€$. When compared with the result of the third year of the optimistic scenario $(€ 16,504)$, we clearly see a remarkable difference between the two options, assuming only $25 \%$ less revenue in sales.

Finally, with respect to liabilities, we must highlight the fact that, compared to the optimistic scenario, the corporate tax payment does not need to be paid, since the company has incurred negative results for the three years.

Then, we will discuss the main indicators (profitability, liquidity, solvency, IRR and NPV) with Table no. 6 , both for optimistic or pessimistic scenario.

Table no. 6 - Main financial indicators

\begin{tabular}{|c|c|c|}
\hline & Optimistic scenario & Pessimistic scenario \\
\hline Profitability & $\begin{array}{l}\text { The financial returns reach } 34.57 \% \text {. Also, the } \\
\text { financial profitability grows } 1.9 \% \text { in the first } \\
\text { year to almost } 35 \% \text { the last year. The assets } \\
\text { turnover moves between } 3 \text { and } 2 \text {, leveraging is } \\
\text { not very high and more than } 1 \text {. It is clearly } \\
\text { profitable. }\end{array}$ & $\begin{array}{l}\text { Economic profitability is negative } \\
\text { for the three years. Financial } \\
\text { returns and margins on sales are } \\
\text { also negative. It would not be } \\
\text { profitable. }\end{array}$ \\
\hline Liquidity & $\begin{array}{l}\text { Background Analysis: Working capital } \\
\text { requirements, liquidity ratio and cash ratio } \\
\text { with very good data. } \\
\text { Cash-flow analysis: very favourable position } \\
\text { with cash flow increasing for the } 3 \text { years. } \\
\text { Clear liquid company. }\end{array}$ & $\begin{array}{l}\text { Analysis Fund: working capital less } \\
\text { than in the optimistic scenario, } \\
\text { liquidity ratio and cash ratio are } \\
\text { decreased in the first two years and } \\
\text { they are improved in the third year. } \\
\text { Cash-flow analysis: Negative cash- } \\
\text { flow for the } 3 \text { years, so partners } \\
\text { need to contribute funds. } \\
\text { Company with liquidity problems }\end{array}$ \\
\hline Solvency & $\begin{array}{l}\text { Background analysis: the net worth is almost } \\
\text { doubling every year. Funding that we are } \\
\text { provided by the suppliers is sufficient to finance } \\
\text { current assets. The solvency ratio ranges from } 4- \\
5 \text { and the debt ratio is low by decreasing the } 3 \\
\text { periods. } \\
\text { Cash-flow analysis: The extra-functional } \\
\text { assets are growing year by year. } \\
\text { Clear solvent company. }\end{array}$ & $\begin{array}{l}\text { Analysis Background: } \\
\text { Net worth and solvency ratio } \\
\text { declining the first two years and } \\
\text { improved the third. } \\
\text { Cash-flow analysis: Extra- } \\
\text { functional assets declining. } \\
\text { The company may issue long-term } \\
\text { solvency. }\end{array}$ \\
\hline $\begin{array}{l}\text { NPV (net } \\
\text { present value) }\end{array}$ & $\begin{array}{l}\text { NPV }=34.205,77 €>0 . \mathrm{k}=0,88 \% \\
\text { The investment would be profitable }\end{array}$ & $\begin{array}{l}\mathrm{NPV}=-31.026,48 €<0 . \\
\text { It would be inadvisable to } \\
\text { undertake the investment }\end{array}$ \\
\hline $\begin{array}{l}\text { IRR (internal } \\
\text { rate of return) }\end{array}$ & $\mathrm{r}=71 \% . \quad \mathrm{r}>\mathrm{k}$. Favourable & r Not possible. Unfavourable. \\
\hline
\end{tabular}

Source: Author's calculations 
378 Jesús Manuel de Sancha NAVARRO, Luis Palma MARTOS, María Dolores Oliver-ALFONSO

\section{CONCLUSIONS}

We intend to design a business plan up to three years for a lyric theatre company, from the estimated ticket sales and following a low-cost strategy in the sector. The conclusions of the plan are:

- For an optimistic scenario, the company LIRICART would get very attractive results from the point of view of profitability, liquidity and solvency.

- However, when taking into account a pessimistic scenario with a decrease of a $25 \%$ in the estimated sales, the situation is clearly insufficient, with negative results for the first years and the contribution of new capital by the partners being necessary, to pay current liabilities. Otherwise, we think the company could even be dissolved.

- Our opinion is that this is an investment undertaken between two extreme and very different situations, and that means taking a high risk. The business idea therefore is not feasible and it is preferable to undertake it in another scenario, due to uncertainty about sales revenue and the impact on the business viability.

- Alternatives: we think that if measures were established to encourage supply and demand (by lowering the cultural VAT, cultural policies that encourage both participation and awareness among younger people, as well as financial alternatives such as crowd funding) perhaps these type of entrepreneurial projects could be undertaken.

- Contributions: We believe this work presents the problem of financial viability that involves the production of live entertainment, within the creative industries, through a feasibility model applied to the performance of zarzuela. This problem, as we have seen above, is due to the rigidity of prices and the high dependence on grants or public demand. Such companies contribute to stimulate short-term expenses on culture and they cause longterm impacts on the productive capacity of the cultural sector of different populations. Therefore, more support and incentives for these companies should be promoted in order to avoid these problems of financial viability.

\section{References}

Albi, E., 2003. Economia de las artes y politica cultural. Madrid: Instituto de Estudios Fiscales.

Aragon, A., and Baixauli, J. S., 2010. El reto de emprender: factores clave. Pamplona: Civitas Ediciones.

Baumol, W. J., and Bowen, W. G., 1966. Performing Arts: The Economic Dilemma. New York: The Twentieth Century Fund.

Camara, M., Canas, L., and Garcia, J., 2000. Creacion de empresas. Guia para su puesta en practica. Jaen: Universidad de Jaen.

Casares Rodicio, E., and al., e., 2002. Diccionario de la Zarzuela. España e Hispanoamérica. Madrid: Instituto Complutense de Ciencias Musicales.

Colomer, J., 2016. Analisis de situacion de las artes escenicas en Espana. Madrid, Spain: Academia de las Artes Escenicas de Espana.

García Agustín, J., 2015. El sistema empresarial 'low cost': Hacia un modelo de gestión. Navarra, Spain: Editorial Aranzadi.

Herrero Prieto, L. C., 2010. La contribución de la cultura y las artes al desarrollo económico regional. Investigaciones Regionales, 18, 221-226.

Junta de Andalucía, 2016. Contribución de la Cultura al Desarrollo Regional y Local. Cultura. from http://www.juntadeandalucia.es/cultura/web/html/sites/consejeria/areas/cooperacion_cultural/Ga lerias/Adjuntos/informe_contribucion_cultura_desarrollo_regional_y_local.pdf 
Economic and Financial Viability Plan for the Entrepreneurship of a Lyric Theatre...

Klamer, A., Petrova, L., and Mignosa, A., 2006. Financing the Arts and Culture in the European Union. Policy Department Structural and Cohesion Policies from http://www.culturalpolicies.net/ web/files/134/en/Financing the_Arts_and_Culture_in_the_EU.pdf

Kotler, P., and Scheff, J., 1997. Strategies for Marketing the Performing Arts. Brighton: Harvard Business Press.

La Red, 2016. Mapa de programación de espacios escénicos asociados. Proyectos. from $\mathrm{http} / / / \mathrm{www}$. redescena.net/proyectos_de la_red/ficha_proyecto.php?id_proyecto=19

Martínez, P. F., Jiménez, F. J. B., Neira, M. Á. A., Sacristán, M. S., Roca, J. M. G.-B., Ania, A. R., . . . Herrero, D. B., 2011. El papel de los Viveros de empresa en la creacion de empleo Empleo y mercado de trabajo (pp. 1-98). Madrid: Universidad Rey Juan Carlos.

Ministerio de Cultura de Colombia, E. C. d. E. y. C. d. C. A. B., 2003. Impacto económico de las industrias culturales en Colombia. Bogotá, Colombia: Convenio Andrés Bello.

Ministerio de Educación Cultura y Deporte, 2016a. CULTURABase. from $\mathrm{http}: / /$ www.mcu.es/culturabase/cgi/um?L=0

Ministerio de Educación Cultura y Deporte, 2016b. Encuesta de hábitos y prácticas culturales 2014-2015. In C. y. D. Ministerio de Educación (Ed.), Catálogo de publicaciones del Ministerio (pp. 438).

Muñiz González, L., 2010. Planes de negocio y estudios de viabilidad: Software con casos prácticos y herramientas para elaborar DAFO y evaluar un Plan de Viabilidad. Barcelona: Profit Editorial.

Muñoz, M., 1946. Historia de la zarzuela y el genero chico. Madrid, Spain: Editorial Tesoro.

Palma M., L. A., and Aguado Q., L. F., 2010. Economia de la cultura. Una nueva area de especializacion de la economia. Revista de Economia Institucional, 12(22), 130-165.

Ploeg, R. v. d., 1999. Ministerie van Onderwijs en Cultuur. Hague: Ondernemende Cultuur.

Pulido, E., 2016. Zarzuela 2.0. Proyecto empresarial para promocionar la zarzuela. (Master proyecto fin de máster), University of Valladolid, Valladolid, Spain.

Ramírez, V., 2013. La subida del IVA es el entierro de la cultura. Cultura. from $\mathrm{http}: / / w w w . e l c o n f i d e n c i a l . c o m / c u l t u r a / 2013-03-22 /$ ldquo-la-subida-del-iva-es-el-entierro-de-lacultura-rdquo_495943/

Rodríguez de las Heras Ballell, T., 2013. El 'crowdfunding': una forma de financiación colectiva, colaborativa y participativa de proyectos. Pensar en Derecho, 2(3), 101-123.

Throsby, D., 2001. Economía y cultura. Madrid, Spain: Cambridge University Press.

Zingales, L., 2015. The "cultural revolution" in finance. Journal of Financial Economics, 117(1), 1-4. doi: $10.1016 /$ j.jfineco.2015.05.006 